\title{
6
}

\section{NATO: Ambiguity about Escalation in a Multinational Alliance}

\author{
Sten Rynning
}

Following Russia's 2014 annexation of Crimea and stoking of civil war in Eastern Ukraine, managing the escalation of conflict between great powers has once again become a central challenge for the North Atlantic Treaty Organization (NATO). Confronted with a great power threat both to their borders and to the continental political order, the allies have reconsidered their powers of denial at the border, as well as their powers of punishment, should the adversary, Russia, breach the border. In this, NATO has the advantage of being able to draw on a long Cold War history of strategising discussion on its concept of 'flexible response', but conditions change: NATO has grown to an alliance of 30 nations, events outside the European theatre pull allies in diverse directions, technology has leapt into a fourth industrial revolution, nuclear weapons remain an object of strong normative concern and Russia's skilful information warfare generates friction in allied threat assessments.

Consequently, the politics of managing escalation have grown more complex, and NATO is therefore explicit on defence and deterrence posture and principle but deliberately vague on escalation. As part of its 'overall posture', the alliance now has an enhanced 'forward presence' along the eastern borders of NATO allies (albeit by rotating troop deployments and exercises, not the permanent stationing of troops) 
reinforced by a layered force structure of reaction, ready and mobilisable conventional forces. ${ }^{1}$ Three of NATO's allies maintain nuclear forces. NATO's principle remains that the purpose of strategic and nuclear forces is to 'preserve peace, prevent coercion, and deter aggression'. It considers any circumstance in which the alliance may be forced to use such weapons 'extremely remote' and that their use would 'fundamentally alter the nature of a conflict'. ${ }^{2}$

NATO's ladder of escalation thus lies between its forward ability to defend its borders and its deterrent capacity to inflict nuclear punishment. It is explicit about the involved conventional-nuclear threshold-that is, the altered nature of a conflict-but not about its political red lines or the steps it will take to manage escalation up to this threshold. To understand why NATO is so committed to a policy of escalatory ambiguity, we must dig into the particular politics of multinational and multilateral deterrence.

\section{The Evolving Challenge of Escalation}

There is a strong undercurrent of continuity in NATO's wrestle with issues of deterrence and escalation that concerns transatlantic geography and exposure to threat. As a rule, European allies seek to minimise the prospect of Europe turning into a theatre of protracted warfare and thus prefer threats of rapid escalation. Inversely, the United States, worried that threats of rapid escalation lack credibility, has tended to favour more paced escalatory options.

When the US prodded NATO in the early 1960s to move away from a strategy of massive retaliation to flexible response, it was effectively seeking to slow the threatened pace of escalation. Prolonged tension in the alliance followed. France's decision to stick to its own strategy of massive retaliation and to step outside NATO's integrated command enabled a wider compromise. NATO adopted a flexible response strategy (MC 14/3) with three escalatory steps: a) direct defence, b) deliberate escalation

1 For the rationale of NATO's enhanced forward presence, see NATO, Warsaw Summit Communiqué, 8-9 July 2016, paragraph 40, www.nato.int/cps/en/natohq/official_texts_133169.htm. 2 NATO, Brussels Summit Declaration, 11-12 July 2018, paragraph 36, www.nato.int/cps/en/ natohq/official_texts_156624.htm. 
controlled in scope and intensity, and c) general nuclear response. ${ }^{3}$ The assurance offered to allies by the US consisted of several measures: that the rationale of 'the threat of escalation' was deterrence; that, should deterrence fail, escalation would be guided by the 'concept of forward defence'; and, finally, that allies gained special access to (US) nuclear plans and policies in a new NATO Nuclear Planning Group.

If striking a balance, as a staffofficer of NATO's Supreme Allied Commander Europe (SACEUR) General Norstad put it, between a 'technical plan for limited warfare' and 'a spirit of unity in NATO' was difficult in the 1960s, such a balancing act is even harder today. ${ }^{4}$ NATO's post-Cold War enlargement has not only introduced the challenge of decision-making by 30 (allies), but also moved NATO territory closer to the border of Russia (principally in the Baltics but also in the Black Sea). The effect is to compress and intensify the process of escalation. Because the confrontation would initially be confined to the Central European space, a Cold War armed confrontation would conceivably not have involved early strikes on US and Soviet territory. In the past, this gave the key decision-making centres, Washington and Moscow, a semblance of opportunity to control escalation by managing both its geographical and its nuclear confines. Today, however, geography has disappeared from this equation: in the case of aggression, NATO would immediately be faced with the decision of whether to retaliate against Russian forces or support infrastructure inside Russia. ${ }^{5}$

Moreover, the presence of Russian minorities in allied countries on Russia’s borders defines an opportunity for Russia to wrap limited military action — such as a land grab operation - in political uncertainty. Minority unrest, politico-legal objections and claims of systematic abuse form part of the information or hybrid warfare toolbox that Russia has explored and continues to develop primarily in Ukraine but also in Georgia and elsewhere, along with measures to disrupt the functioning of targeted government and society.

3 NATO, Final Decision on MC 14/3: A Report by the Military Committee to the Defense Planning Committee on Overall Strategic Concept for the Defense of the North Atlantic Treaty Organization Area, 16 January 1968, www.nato.int/docu/stratdoc/eng/a680116a.pdf.

4 Timothy Andrews Sayle, Enduring Alliance: A History of NATO and the Postwar Global Order (Ithaca: Cornell University Press, 2019), 83.

5 See Hans Binnendijk and David Gompert, 'Decisive Response: A New Nuclear Strategy for NATO’, Survival 61(5), 2019, 113-28, doi.org/10.1080/00396338.2019.1662119. 
Finally, Russia benefits from Europe's political geography in the sense that it is capable both of mobilising significant military force in a short time and of choosing the time and place of their operation. Inversely, NATO is constrained by its commitment dating back to 1997 to carry out collective defence by 'interoperability, integration, and capability for reinforcement' rather than 'by additional stationing of substantial combat forces' on the territory of post-Cold War NATO allies. ${ }^{6}$

In summary, escalation involves two dilemmas for NATO. One is the classical dilemma between European and American interests in fast versus paced escalation. Another is a new dilemma between, on the one hand, the need for a posture of decisive and rapid military action to deny Russia opportunities for limited aggression, and, on the other, a need to maintain strict measures of political control to prevent a local crisis from escalating inadvertently to general war.

\section{Political Guidance}

To navigate these dilemmas, NATO should settle on political principles to guide military planning. However, in practice, NATO has addressed such principles in a piecemeal and evolving fashion and is only now, in 2021, preparing for a revision of its overarching strategic concept.

NATO has primarily relied on summitry to calibrate its political messagein Wales (2014), Warsaw (2016) and Brussels (2018) — which is primarily one of condemnation: Russia's actions are labelled 'aggressive' (Wales), 'provocative', 'destabilising' and 'illegal and illegitimate' (Warsaw and Brussels). However, it is also one of restraint: NATO remains attached to the old framework of partnership (entered into in 1997 and updated in 2002) and believes its own actions to enhance defence and deterrence take place in respect of this framework, whereas Russia is violating it.

While NATO officialdom defends the wisdom of this balancing act with reference to a dual-track framework of both 'defence' and 'dialogue' - a heralded balancing act in NATO dating back to its 1967 Harmel doctrine - the fact is that NATO has struggled to reach agreement on its assessment of the Russian threat. The Trump presidency

6 NATO and Russia, Founding Act, 27 May 1997, www.nato.int/cps/en/natohq/official_texts _25468.htm. 
proved to be debilitating: for as long as the alliance leader was unable to define its own Russia policy, partly out of President Trump's anxiety that it could question the legitimacy of his 2016 presidential election, NATO was stuck. In Europe, the allies geographically close to Russia sought a hard line, but Mediterranean allies sought a balanced East-South policy, and Western allies such as Germany and France sought a balanced defence-and-dialogue policy. A number of Western allies, including Canada, the United Kingdom and the Netherlands, supported a tough policy but lacked the military hardware that Eastern allies requested as evidence of a firm policy.

In consequence, NATO has politically been unable to define the desired effects for which military planners are supposed to plan. Its 2010 Strategic Concept, which is still in force, puts collective defence on par with crisis management operations and cooperative security. While NATO quickly agreed in a post-2014 setting that it needed to think differently about Russia, gaining substantial political agreement has been a challenge. NATO has sought a defence-and-dialogue balance, as mentioned, and it has also-in its 2019 political guidance issued to military authoritiesenhanced its level of ambition to a 'major joint operation plus', meaning a significant conventional armed confrontation with Russia. However, while this upgrade addresses the level of threat-which is to say that military capability requirements increase-it did not address the nature of the threat: that is, how Russia is expected to act, and what NATO should be capable of doing in order to deter it.

It remains an open question whether a revised 2022 Strategic Concept will enable the identification of such desired military effects. The secretary general's 'Food for Thought' paper, which kicked off high-level NATO deliberations in February 2021, mentions Russia just once, and this in conjunction with China as part of an 'authoritarian pushback against the rules-based international order'. 7 From the point of view of managing escalation, it is a start, but only just.

7 NATO Secretary General, Food for Thought Paper: NATO 2030 - A Transatlantic Agenda for the Future, Document PO (2021) 0053, 11 February 2021, NATO Unclassified. 


\section{Conventional Force}

While the political level is struggling to interpret Russia, the military level has advanced beyond this point. Naturally, NATO military planning is guided by political considerations and does not exceed political boundaries, but NATO military authorities have had to confront the meaning of Russia's military challenge or threat in a markedly direct way.

The search for 'coherence'-an often-invoked keyword when NATO military officials speak on background-began in the wake of the 2014 Wales summit, which directed military authorities to deliver on both 'assurance measures' (rotational military presence to assure exposed allies) and 'adaptation measures' (force and command structure reforms to ensure future defence and deterrence capability). ${ }^{8}$ Through a long and winding road marked in part by the aforementioned absence of politically defined 'desired effects', NATO's military authorities produced first a new NATO Military Strategy (MC400/4), approved by the Military Committee in May 2019, and then a concept for Deterrence and Defence of the Euro-Atlantic Area (DDA), approved by defence ministers in June 2020. ${ }^{9}$

The outcome is a markedly improved deterrence posture comprising forward-deployed troops (again, rotational and not permanently deployed), enhanced reaction forces and follow-on forces. NATO's command structure has also been revamped, gaining a third Joint Force Command in Norfolk, USA, to assure transatlantic links, as well as a Joint Support and Enabling Command in Ulm, Germany, principally to connect NATO's Western European seaboard to the frontiers of Eastern allies. ${ }^{10}$

In terms of escalation, the posture is deliberately ambiguous. To counter Russian advantages in speed and choice of location, NATO is best off approaching the European theatre as one integrated theatre of (potential) conflict and to offer its supreme commander, SACEUR, the authority and means of rapid reaction. And this is precisely the direction in which the 2020 DDA concept is moving: it is a 'theatre-wide' approach meant to deter Russia by the robustness and unpredictability of NATO's response.

8 'Wales Summit Declaration', Press Release, NATO, 5 September 2014, paragraphs 5-13, www. nato.int/cps/en/natohq/official_texts_112964.htm.

9 These meetings are followed by press conferences, not communiqués or declarations. For the Military Committee meeting, see '181st Military Committee in Chiefs of Defence Session', NATO, 22 May 2019, www.nato.int/cps/en/natohq/events_166141.htm?selectedLocale=en. For the Defence Ministerial, see 'Meetings of NATO Ministers of Defence', NATO, 17 June 2020, www.nato.int/cps/ en/natohq/events_176298.htm?selectedLocale=en.

10 The two other Joint Force Commands are in Brunssum, the Netherlands, and Naples, Italy. 
If NATO is not going all-out in implementing a theatre-wide escalatory policy, it is because of issues of political control. First, allies are not in agreement on how far to go in building up a 'heavy metal' response to Russia. Eastern allies are alarmed and seek the build-up of significant armoured projection capability from West to East; other allies seek a lighter touch. For as long as this tension remains, NATO military authorities will have to labour on a middle ground of enhancing the readiness and mobility of sizeable but not overwhelming conventional forces. ${ }^{11}$

Second, most allies are reluctant to give up on the geographically compartmentalised response plans that NATO introduced in 2015 (so-called Graduated Response Plans). While allies recognise the need to deter Russia through strategic agility and SACEUR command options, they also, and each in their own way, worry that SACEUR, were he to be liberated to act flexibly within the full theatre, might de-emphasise deterrence in their particular neighbourhood. Relatedly, SACEUR flexibility could introduce the type of paced or 'horizontal' escalation European allies tend to abhor because it could prolong a conventional war in Europe. Hence, they insist that theatre-wide planning must proceed on the basis of geographically narrow response plans. It remains for NATO to work out a political framework for deciding on and managing such horizontal escalation without entirely inhibiting it. $^{12}$

Finally, Mediterranean allies worry that all the talk about Russia implies decreased attention and resources to 'southern' threats-which, in NATO-speak, are 'international terrorist groups'. At the insistence of these allies, NATO's 2019 Military Strategy has to equally address Russia and the consequences of instability in NATO's south. The alliance's concept for DDA and other plans and policies are therefore embedded in references to '360 degree' thinking and approaches that disguise sometimes deep political disagreement. Thus, in the year spanning 2019-20, Turkey blocked the political approval of NATO's Graduated Response Plans as a measure to force NATO to recognise Kurdish groups in Syria as terrorist entities. ${ }^{13}$

11 In part the enhancement of NATO's Response Force; in part the improved readiness of 30 mechanised battalions, 30 air squadrons and 30 combat vessels — ready to go in 30 days or less (hence, a 4 × 30 readiness initiative).

12 See Sten Rynning, 'Deterrence Rediscovered: NATO and Russia', in Deterrence in the 21st Century: Insights from Theory and Practice, ed. Frans Osinga and Tim Sweijs (The Hague: Asser Press, 2020), 29-46, doi.org/10.1007/978-94-6265-419-8_3.

13 Robin Emmott and John Irish, 'Turkey Still Blocking Defence Plan for Poland, Baltics, NATO Envoys Say', Reuters, 17 June 2020. 
Political control, therefore, concerns a multitude of sensitive issues at the highest level of NATO: the nature of the Russian threat, options for horizontal escalation within theatre and the relative merits of other threats and theatres of concern. It is safe to predict that NATO can improve upon some of these issues but not overcome them, and the policy of escalatory ambiguity will thus remain in one shape or another.

\section{Nuclear Force}

Unlike its conventional posture, NATO is not seeking to change its nuclear posture. It maintains a number of principles that have emerged out of years, if not decades, of careful diplomatic adjustment: for example, that nuclear weapons are unique and for the preservation of peace, not war; that as long as nuclear weapons exist, NATO will remain a nuclear alliance; that NATO will defend and deter with an appropriate mix of nuclear, conventional and missile defence capabilities; and that UK and French nuclear forces contribute to alliance deterrence while US nuclear forces, some of them forward deployed in Europe, remain central to deterrence. ${ }^{14}$

Continuity in the nuclear posture was questioned in 2017-18 when experts established that Russia's ground-launched cruise missile SSC8 was fully developed, deployed and in violation of the Intermediate-Range Nuclear Forces (INF) Treaty. ${ }^{15}$ In the course of 2018, the US Nuclear Posture Review called for investment in US intermediary nuclear capabilities (mainly sea-based), and the US withdrew from the INF Treaty. For NATO and, in particular, the European allies, the question was whether these developments implied a lowered threshold for nuclear conflict and, by implication, eroding trust in Washington in strategic nuclear deterrence.

NATO contained these potentially disruptive questions in a posture of continuity. ${ }^{16}$ The countermove to Russia's SSC 8 is thus not the forward deployment of more US nuclear weapons-unlike the dual-track decision

14 See NATO, Brussels Summit Declaration, paragraphs 33-36.

15 Russia did not share the assessment and countered that the US violated the INF Treaty with its Aegis Ashore missile defence system.

16 For more on the disruptive potential, see Michael Rühle's chapter in this volume as well as Stephan Frühling, 'Managing Escalation: Missile Defence, Strategy and US Alliances', International Affairs 92(1), 2016, 81-95, doi.org/10.1111/1468-2346.12501. 
of 1979-but further investment in the 'safety, security, and effectiveness' of NATO's existing nuclear option. In practice, this means enhanced surveillance and reconnaissance as well as air defence capabilities, and intensified training of the nuclear chain of command from the North Atlantic Council to military units. Finally, it means continuity in terms of the upgrading of nuclear-sharing arrangements between the US on the one hand and Belgium, Netherlands, Germany, Italy and Turkey on the other. ${ }^{17}$

Moreover, NATO's nuclear deterrence posture is defined by the principle of strategic deterrence: any use of nuclear weapons would change the nature of the conflict. This posture sends a strong message to Russia and allows NATO to divert normative and political controversy at home. The fact that the most vocal proponent of a massive retaliation deterrence posture, France, now has troops at Russia's border as part of the alliance's enhanced forward presence and inside an alliance posture that remains, at heart, one of flexible response, raises interesting questions for a meeting of nuclear minds in NATO. However, this meeting of minds takes place outside NATO's Nuclear Planning Group, where France continues not to take part, and in the informal corridors of high-level US, British and French consultations.

NATO is dedicated to strengthening deterrence through pursuing a robust posture and escalatory ambiguity. Robustness and ambiguity follow from the full-spectrum political imperative in NATO of countering Russia, assuring geographically exposed allies and catering to a complex and diverse range of sensitivities that 30 allies bring to the table. NATO's 2022 Strategic Concept will likely advance and deepen the alliance's appreciation of the threat posed by Russia as well as the military robustness with which NATO must respond. With careful preparation, the outcome will be an improved posture. On the subject of escalation, NATO may succeed in clarifying its approach to theatre-wide conventional defence and deterrence, but the basic need for escalatory ambiguity will remain, certainly where it concerns the conventional-nuclear threshold.

17 Nuclear sharing refers to the stationing of US gravity bombs (B61) and allied means of delivery (F15, F16 or Tornado aircraft) as well as secure base facilities. For an outline of NATO's posture, see 'Press Conference by NATO Secretary General Jens Stoltenberg Following the Meetings of NATO Defence Ministers', NATO, 17 June 2020, www.nato.int/cps/en/natohq/opinions_176520. htm?selectedLocale=en. 
This text is taken from Alliances, Nuclear Weapons and Escalation: Managing Deterrence in the 21st Century, edited by Stephan Frühling and Andrew O'Neil, published 2021 by ANU Press, The Australian National University, Canberra, Australia.

doi.org/10.22459/ANWE.2021.06 